\title{
Anne de Graville Translates Alain Chartier: Identifying the Manuscript Source in the Margins of B.N. fr. 2235
}

\author{
Joan E. McRae \\ Middle Tennessee State University \\ joan.mcrae@mtsu.edu \\ https://orcid.org/OOOO-OOO3-1843-9866 \\ Received: o7/04/202O; accepted I5/o6/202O \\ DOI: https://doi.org/IO.7203/MCLM.7.I7OIO
}

\begin{abstract}
An examination of the single manuscript of Anne de Graville's Rondeaux, a 'translation' of Alain Chartier's La Belle Dame sans mercy, as well as consideration of Carl Wahlund's I897 critical edition reveals that Anne used several manuscripts and early printed editions in establishing the version of Chartier's poem written in the margins of BN fr 2253. The base exemplar was most likely St. Petersburg, National Library of Russia MS fr. $f^{\circ}$ v. XIV. ooo?, with variants found in BN fr 20026 , BN fr 924, and the early printed editions.
\end{abstract}

KEYWORDS

Anne de Graville; Alain Chartier; Louis Malet de Graville; Marie de Clèves; Jacques Thiboust; manuscript; BN fr. 2253 , BN fr. 924; BN fr. 20026; St. Petersburg National Library of Russia MS fr. f ${ }^{\circ}$ v. XIV. ooo7; Carl Wahlund, Rondeaux; La Belle Dame sans mercy; women translators; medieval literature; Renaissance literature; French literature

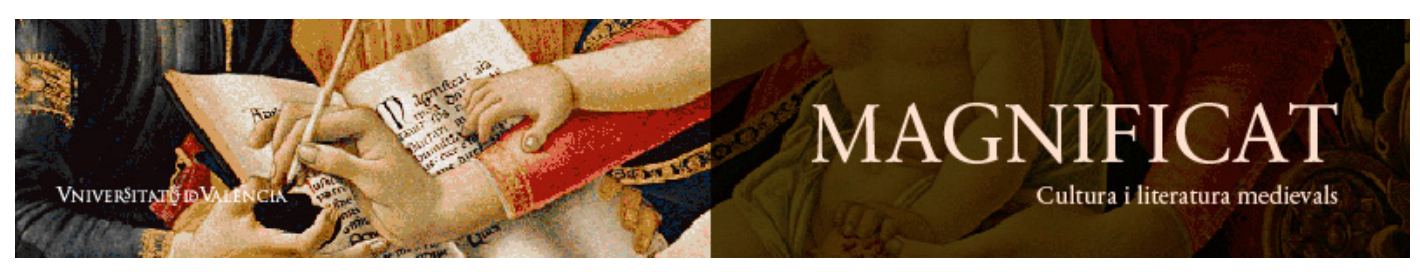

Magnificat Cultura i Literatura Medievals 7, 2020, I87-209. http://ojs.uv.es/index.php/MCLM

ISSN $2386-8295$ 
RESUM

Estudi del manuscrit únic del Rondeau d'Anne de Graville, una mena de traducció de La Belle Dame sans mercy d'Alain Chartier. La consideració del testimoni de I424, així com de l'edició crítica de Wahlund en I897, revelen que Anne va emprar diversos manuscrits i postincunables per establir la versió del poema de Chartier escrita en els marges del ms. BN fr 2253. L’exemplar base va ser, molt probablement, Biblioteca Nacional de Rússia en Sant Petersburg MS fr. $\mathrm{f}^{\circ} \mathrm{v}$. XIV. oOO7, amb variants presents a BN fr 20026, BN fr 924, i els postincunables.

PARAULES CLAU

Anne de Graville; Alain Chartier; Louis Malet de Graville; Marie de Clèves; Jacques Thiboust; manuscrits; BN fr. 2253, BN fr. 924; BN fr. 20026; St. Petersburg National Library of Russia MS fr. f ${ }^{\circ}$ v. XIV. ooo7; Carl Wahlund Rondeaux; La Belle Dame sans mercy; dones traductores; literatura medieval; literatura del Renaixement; literatura francesa

Joan E. McRae. 2O2O. 'Anne de Graville Translates Alain Chartier: Identifying the Manuscript Source in the Margins of B.N. fr. 2235', Magnificat Cultura i Literatura Medievals, 7: I87-209, DOI: $\underline{\text { https:// }}$ doi.org/IO.7203/MCLM.7.I7OIO

\section{TABLE OF CONTENTS}

I Introduction - I89

2 Manuscript of the Rondeaux, BN fr. 2253 - 190

3 Alain Chartier and the Quarrel of the Belle Dame sans mercy - 192

4 Wahlund's Edition of the Rondeaux - I96

5 Manuscripts in Anne de Graville's Milieu - 197

5.I Bibliothèque nationale, français 20026 and its pendant BNfr. 2230 - 197

5.2 Bibliothèque nationale, français $924-198$

5.3 St. Petersburg, National Library of Russia MS fr. f ${ }^{\circ}$ v. XIV. 0007 - 199

6 Variant Readings and Conscious Interventions - $2 \mathrm{OI}$

${ }_{7}$ Conclusion - 204

8 Works Cited - 206

8.I Manuscripts containing works by Anne de Graville - 208

8.2 Manuscripts cited owned by Anne de Graville - 208

8.3 Manuscripts cited containing works by Alain Chartier - 209

8. 4 Early printed editions - 209

8.5 Other - 209 


\section{ə*⿻}

\section{Introduction}

Sometime before I525 Anne de Graville (c.I49O-C.I540), author and humanist at the court of François I and his first queen Claude de France, undertook the task of 'translating' the text of Alain Chartier's La Belle Dame sans mercy, updating the narrative and neutral octosyllabic form of Alain's poem to a lyrical and courtly form of rondeaux.

It is no wonder that Anne would be attracted by this tale of a woman who steadfastly refuses the pleas and threats of a would-be lover. She herself lived out the conviction declared by the female character of Chartier's poem, the belle dame: "choisisse qui vouldra choisir" let her choose who wishes to choose (Belle Dame sans mercy, v. 285). Anne was born into one of the oldest, wealthiest, and most well-connected families in France. Her father, Louis Malet de Graville, (I438- $\left.{ }^{8} 5^{\mathrm{I} 6}\right)$, Admiral of France, governor of Normandy and Picardy, lord of Graville, Montaigu, Marcoussis, Bois-Malesherbes, had served nobly under three kings: Louis XI, Charles VIII and Louis XII. He held high expectations for the marriages of his three daughters. Her two sisters, much older than she, had already made illustrious alliances, Jeanne with Charles d'Amboise and Louise with Jacques de Vendôme. But Anne defied her father and chose the one she would love. Around I5O7 she was abducted from her family's home at the château of Marcoussis by Pierre de Balsac d'Entraigues (c. I465-c. I53O), cousin on her mother's side, a young man who perhaps did not meet the Admiral's high expectations for his youngest daughter. Her lover's aim was true, however. Pierre demonstrated his adoration and respect for Anne with a most appealing gift for her: a lavishly produced manuscript of a translation of the Chaldean Histories, his "book of love" (L'Estrange 20I5). Containing the quasi-historical writings of Berosus the Chaldean, this book does not explicitly deal with love, but it does signal admiration of Anne's love for learning and Pierre's respect for her erudition (L'Estrange 2OI5: 7II). Her education, gift of her bibliophile father, brought her fame and close contact with well-known court figures such as Queen Claude, the king's mother Louise de Savoie, and the king's sister Marguerite de Navarre, ladies equally interested in les beaux arts.

For her efforts at self-determination in love, Anne incurred her father's disappointment and wrath, leading to lengthy lawsuits and disinheritance at her father's death in I5I6. She sued, however, and regained her third of the inheritance although it took some years to accomplish. After I5I8 Anne and Pierre were awarded their part of her father's possessions, including domains in Normandy and central France, a grand house in Paris, and most importantly, a large portion of Louis Malet de Graville’s extensive library, which she would further develop with her own acquisitions. This wealth of literary resources would serve to inform Anne throughout her life (Montmorand igiz: 62-85; Deldicque 2019). ${ }^{\text {. }}$

By I5I5, Anne came to the royal court to serve Claude (I499-I524) - eldest daughter of Louis XII and his second wife Anne of Brittany -, who became queen of France when her husband François I took the throne a year after their marriage. Anne was following in the model of her elder sisters: Louise had been lady-in-waiting later in her life to Anne de Beaujeu, and Jeanne chose to live with Jeanne de France, the repudiated wife of Louis XII, after the annulment of her marriage to the king. Queen Claude's court was somber and dignified and the ladies lived modestly, decently, and

I. Elizabeth L'Estrange's Anne de Graville and Early Modern Book Culture in France, forthcoming from Boydell and Brewer, consolidates, updates, and verifies biographical and bibliographic information. 
in austerity, as they had been taught: "Claude's court was a center where learning, good morals, and female virtue were actively cultivated" (Delogu 20I7: 473). ${ }^{2}$ This atmosphere appears to have refocused Anne's passion to the production of poetry.

Before Claude's death in I524, Anne produced two works for the queen. Wilson-Chevalier proposes that a social climate compromised by the open promiscuity of the king provided motivation for Anne’s work: “As François I's promiscuity gained heightened visibility, Graville ... proposed models for refashioning a newly respectful breed of men" (2OIO: I28). Indeed, both of Anne's works treat social issues and the interaction of men and women. Her work highlights the power available to a woman. Bouchard suggests that "Speaking to and for the queen, Graville perhaps envisaged her role as both an agent for women of the court in general and as her own defender, for having taken destiny into her own hands" (2018: 242). The most popular, or at least the most frequently copied, of Anne's works is a rhymed translation of Boccaccio's fourteenth century Teseida, disseminated as Le Beau Romans des deux amans Palémon et Arcita, et de la belle et saige Emilia, now preserved in six manuscripts 3 . The second work is the ‘translation' into rondeaux of Alain Chartier's Belle Dame sans mercy. The Rondeaux, preserved in BN fr. 2253, is the work that concerns us here. ${ }^{4}$

\section{Manuscript of the Rondeaux, BN fir. 2253}

$\mathrm{O}$ court, the manuscript does not appear in the $\mathrm{I}_{5}^{\mathrm{I} 8}$ catalogue of the Royal Library at Blois. Nor does it appear in the 1544 catalogue drawn up on the occasion of the library's move to the château of Fontainebleau, or after the move of the books to Paris after 5567 . It does, however, appear in the Rigault catalogue compiled in I622, inscribed as MMCLXV $(2 \mathrm{I} 65)$ and described as "La belle dame sans mercy en vers francois" (Omont I9O8-2I, 2: 37I) ${ }^{5}$ There is nothing in the manuscript to indicate that it ever left the royal court, although it may have been kept as part of the private collection of the family before being entered into the formal library. ${ }^{6}$ The surviving copy of the narrative sequence of rondeaux, $\mathrm{BN}$ fr. $2253,{ }^{7}$ is a manuscript containing a single text, copied on parchment and decorated with gold lettering enhanced by flourishes of color, alternating blue and red. An eighteen-line decasyllabic prologue opens the text. There is no title, but its recipient is addressed in red ink: "A ma dame". In the lower margin a banderol with the anagram "J'en garde un leal" was the clue that allowed Carl Wahlund, in the I8gos, to identify Anne as the author of the manuscript's text.

2. Delogu (2OI7: 473) reminds us of an influential book of Claude's youth, her primer (Cambridge, Fitzwilliam MS I59) with its illumination of St Anne teaching the Virgin Mary to read, surely a strong inducement to follow the Virgin's example.

3. Paris, Arsenal, 5II6; Paris, BNF fr. ı397; BNF fr. 2544I; BNF n.a.f., 65ı3; BNF n.a.fr., 7І19; and Chantilly, Musée Condé, I57O.

4. It is possible that a second copy was produced. Elizabeth L'Estrange (2015) has discovered a misplaced title page with a motto belonging to Claude's mother-in-law, Louise de Savoie and the title "La belle dame sans mercy mis en rondeaux" with a dedication illumination to Louise on the verso. This may indicate a second copy made for her, or perhaps suggest that Claude was not the original patron or that the work was written later, after Claude's death, for Louise de Savoie. More information on this possibility will appear in her forthcoming book.

5. Omont's catalogues can now be consulted online: $\langle$ https://tinyurl.com/y2W4VZXp $>$.

6. Salda suggests that additional manuscripts were held in the royal family's "personal collections" (I994: 22 note I) that do not show up in the catalogue of the royal library.

7. The abbreviated form $\mathrm{BN}$ fr. will be used in place of Bibliothèque nationale, fonds français. 
In the outer margins of each folio are copied the verses of Chartier's poem, positioned so that the reader can easily see how Anne has rendered the medieval octosyllabic interlaced rhyming stanzas into her own decasyllabic rondeaux. Müller expresses how the manuscript's arrangement serves Anne's purpose:

Les transformations formelles introduites par Anne de Graville dans le texte d'Alain Chartier sont immédiatement perceptibles à l'ouverture du manuscrit : la poétesse réélabore les huitains d'octosyllabes de son prédécesseur en rondeaux de décasyllabes, répondant ainsi à une forme neutre et narrative par une forme courtoise et musicale, courtoise parce qu'elle s'emploie traditionnellement pour signifier le don amoureux, et musicale parce qu'elle fait la part belle au refrain, qui par son multiple retour, rappelle la danse en rond à l'origine de son nom. Le choix du rondeau permet de jouer à la fois sur la circularité, la réitération et l'emphase ; l'emploi de quinze décasyllabes pour transposer les huit octosyllabes permet évidemment l'amplificatio et l'ajout. (Müller 2003: 7)

Müller indicates how Anne is transforming Alain's verses to be suitable for her own time and place, mentioning the use of amplificatio and l'ajout; we might suggest that she also makes use of the other compositional strategies of Classical rhetoric: abbreviatio, translatio, alteratio, an indication that Anne is applying her classical training in the rhetorical arts to her task.

But is this transformational exercise a translation or a rewriting? Perhaps these two terms indicate the same process. Reference to contemporary rhetorical theorists such as Gerard Genette and André Lefevere would suggest that this is the case. Réka Forrai sketches a blueprint of how classical and medieval translators and authors held the same ideas and employed the very strategies detailed by modern theorists, that translation is rewriting and rewriting is translation. Genette, for example, would qualify Anne's work as a hypertext modality; as Forrai explains it, for Genette "every text is a hypertext connected to an earlier hypotext that it modifies through transformation or imitation" (Forrai 20I8: 29). Structurally, Anne's hypertext transforms even as it imitates and translates Alain's hypotext. Lefevere, for his part, considers translation from a different angle, one of rewriting. Forrai cites Lefevere's association of translation with rewriting and his comment on the "constraints" that influence this kind of writing:

Translation is, of course, a rewriting of an original text. All rewritings, whatever their intention, reflect a certain ideology and a poetics and as such manipulate literature to function in a given society in a given way. Rewriting is manipulation, undertaken in the service of power, and in its positive aspect can help in the evolution of a literature and a society. (Forrai 20I8: 30, n. II)

In rewriting Chartier's verses, Anne functions under the constraints of power (the court) and the expectation of a modernized sensibility for poetics as she transforms her model to suit her own courtly purposes. In rendering the poem more appealing for Queen Claude's decorous court, Anne updates the verse form even as she invites a dialogue with this purportedly un-courtly poem. L'Estrange explains (20I5: 724) that through the arrangement of the two texts "further attention is drawn to the notion of translation and rewriting through the mise-en-page of the only surviving copy of the Rondeaux where Anne's text is presented in parallel with Chartier's original. The two are thus textually and visually in direct dialogue in a format that encourages comparison and debate".

The structural re-fashioning of form, visual and sonic, enacted by Anne is immediately apparent. The dialogic level, however, is not so obvious. What, exactly, would Anne be dialoguing with

8. The two versions are only briefly in parallel, until ff. I2V-I3r. 
Alain about? What is it that she is rendering more courtly? ${ }^{9}$ Some elucidation of Alain Chartier's reputation may suggest an answer to these questions.

\section{Alain Chartier and the Quarrel of the Belle Dame sans mercy}

Some one hundred years before Anne found herself at the royal court, Alain Chartier served Charles VII as royal secretary, notary, advisor, and ambassador during the very difficult years of the dauphin's exile, disinheritance, and struggle to regain his father's throne from the Burgundians and the English invaders. Alain was a political man, but also a poète engagé who was committed to inspiring patriotism in his readers (Blanchard et al. 2002). He was devoted to his king and his country, and wrote passionately about the crisis the country found itself in - civil war in the royal family, encroaching enemies from abroad, and the people's desperate plight to survive a severe deprivation of resources. Alain also wrote love poetry, and was hailed as the "père de l'éloquence française" by the sixteenth century. His work served as a model for French poetry, his name an authority to be invoked as it frequently was throughout the sixteenth century. He was cited in six treatises of rhetoric written by the likes of Jean Molinet and Pierre Fabri and was included in Vérard's Fleur de Rhetorique. Beyond poetry, "Alain is a moral guide for his readers, to whom he proposes models of action that conform to his idea of virtue and the common good" as Florence Bouchet so succinctly sums up his reputation (Bouchet 2OI5: 325; Hoffman I942: I62).

The esteemed status of Alain's poetry was reason enough for Anne to choose his verses to adapt, especially if her aim was morality. Of all his poems, Anne says in the first lines of her introduction to the Rondeaux that she found La Belle Dame sans mercy the most to her liking: "En maistre Allain de ses oeuvres j'ay quis, A mon juger le plus fin et exquis...”. But there was another matter closely associated with this poem that had to be addressed. This brief 8oo-line poem had created quite a scandal after it was circulated in I 424 or I 425 .

La Belle Dame sans mercy was ostensibly recorded by an eavesdropping author-narrator. The debate featured a forthright lady who firmly refused the advances of her love-struck lover, contradicting his time worn and rhetoric-laden love language with reason and alacrity. At the end of the poem, the lady leaves the lover in the garden and returns to the dance. The narrator says that he heard later that the lover died of heartache from the rejection. Members of Charles VII's court, living in Touraine since the Burgundians had retaken Paris, were dismayed by Chartier's verses. Following the poem in almost all of its forty-five manuscripts, are copied two letters written by members of the royal court to put forth their objections. In the first letter, addressed to the ladies, called the Requeste baillee aux dames contre alain, the courtiers outline their complaints regarding Chartier's poem: this eloquently written dialogue threatens to sabotage their pursuit of love, the "queste du don d'amoureuse mercy"; its author is an envious or disgruntled lover who is trying to spoil others' chances at love, and its hard-hearted heroine may inspire imitators, ruining the reputation of all good ladies. The ladies should refuse to read it and destroy all copies. In response, the ladies, who sign their names Katherine, Marie, and Jehanne, ${ }^{\text {Io }}$ compose a letter to Alain, in which they warn him

9. Müller queries: “A-t-elle cherché, à travers ses rondeaux, à offrir une autre vision de la Belle Dame cruelle et de l'amant transi?" (2003: 5). Interpretations of La Belle Dame sans mercy abound; see especially Calin (2006) for a bibliographic review.

IO. These names were not uncommon at the time. Pierre Champion notes, however, that the list of Marie d'Anjou's six ladies-in-waiting at the court of Issoudun includes Jeanne Louvet, Marie Louvet, and Catherine de l'Isle-Bouchard (I923: 7I). Were these the ladies in question? 
of these complaints that might tarnish his reputation. They request, in a tone that indicates their fondness for him and his poetry, that he defend himself against these accusations.

Alain, who was absent from the court on ambassadorial duties, ${ }^{\text {II }}$ nevertheless took the time to respond to the ladies in a 244-line dream allegory, his Excusation aux dames. The God of Love appears to him and, echoing the accusations of the courtiers, chastises him for his poem:

Es tu fol, hors du sens ou yvre,

Ou veulx contre moy guerre prendre,

Qui as fait le maleureux livre,

Dont chascun te devroit reprandre,

Pour enseignier et pour aprendre

Les dames a getter au loing

Pitié debonnaire et tendre,

De qui tout le monde a besoing?

(McRae ed. 2004: v. 25-32)

If he is embittered from love, he should not punish others, nor should he teach ladies to be merciless. Alain responds to the God of Love, and indirectly to the courtiers, with an apology and a multipronged defense. He charges readers to read the whole poem so that they might judge it in its complete context (Vv. I2I-I24) and not misunderstand his intent. Moreover, surely the God of Love would agree that women do not, nor should they, grant their love to whomever might request it (vv. I53-76). He denies that he ever said women were without pity, though the lover, struck with grief, may have made the mistake of saying such a thing (vv. I77- 208). But should he be blamed for simply recording the debate that he happened to overhear?

\footnotetext{
S'en doit tout le monde amasser

Contre moy a tort et en vain,

Pour le chetif livre casser

Dont je ne suis que l'escripvain?

(vv. 2I3-I6)
}

He reiterates vigorously his dedication to ladies: "Par elles et pour elles sommes" (v. I37) and his courtly intention to remain until his death in their service: "Leur serviteur vueil demourer / Et en leur service mourray" (vv. I45-46). The God of Love is satisfied with his apology and reaffirmation of his commitment to women. He remands the case to the ladies to judge and Chartier begs the ladies to forgive him even as he promises to return to them when he can. The case appears to be resolved.

In four manuscripts, however, an additional letter, the Response des dames faicte a maister Allain excoriates Alain even more harshly. The severe tone of the letter recalls the courtiers' letter, more so than the ladies', despite its attribution to them. The versified letter, responding directly to his Excusation, again condemns Chartier for his portrait of women as heartless, pitiless, and cruel. Alain is offered the choice of two judgments, to be killed or to take back what he has written: "Ou tu mouras, ou il t'en fault desdire (v. 87)". If he refuses to comply, they will present their case against him to Love with the help of lawyers: "nos avocatz Dessarteaulx et Chastel" (v. IO4).

Arthur Piaget, one of the earliest modern scholars to study what would become known as the Quarrel of the "Belle Dame" suggested that a less violent, perhaps parodic version of this sentence

II. For more details about Chartier's ambassadorial duties at this time, see Laidlaw I974: 5-8. 
was carried out by a cour amoureuse at Charles VII's exiled court. ${ }^{12}$ In a manuscript of the Lay de Guerre, written by Chartier's friend Pierre de Nesson, also living in exile in the entourage of Charles VII, one of his characters describes Chartier as

Lui qui jadis fut, anmy d'Issouldun,

Present son roy et tretout le commun,

Publicquement banni a son de trompe

(Piaget ed. I9OI: 36 )

Whether Chartier was really ostracized from some literary love court or whether this passage is a joke meant to poke fun at Chartier is unclear. ${ }^{13}$ The later seems more likely since we do know that Chartier continued in royal service and continued to write poetry and prose for his courtly audience.

The controversy over Chartier's poem was not put to rest, however. Instead it was propagated through a variety of literary continuations, often enhancing the judicial overtones introduced by the epistolary quarrel. In much of the manuscript tradition of Chartier's French poetry, the Belle Dame, the letters and Excusation, are followed by some or all of four sequential poems that put Chartier's lady on trial for the willful murder of her would-be lover, a cycle of poems that would be labeled in one manuscript as the "le livre de la belle dame sans mercy". ${ }^{\mathrm{I}}$ In the initial trial, Les Accusations contre la belle dame sans mercy, attributed to Baudet Herenc and extant in nineteen manuscripts, the belle dame is called before the allegorical court of love and accused of murder, but, finding no lawyer willing to defend her, the trial is suspended. In the second anonymous trial, $\mathrm{La}$ Dame loyale en amour, extant in thirteen manuscripts, the belle dame is defended by the lawyers Truth and Loyalty who reveal that the reason the belle dame did not acquiesce to the lover's request was because she was remaining true and loyal to a secret lover, as the rules of love require. Thus justified, she is renamed the Loyal Lady. In the third trial, the lawyers Truth and Loyalty from the previous trial are unmasked as the tricksters Fiction and Falseness who used the lie of a secret lover to acquit the lady. The lady is tried again in the Cruelle Femme en amour, written by Achilles Caulier and extant in seventeen manuscripts. This time she is condemned by her own words, renamed the cruelle femme, and sentenced to drowning in the well of tears. In the final anonymous trial poem, Les Erreurs de la belle dame sans mercy, extant in three manuscripts, the ancestors of the lady attempt unsuccessfully to reverse the previous decision. It is not just the belle dame who is criticized in these trials; Alain Chartier himself is blamed for having created a character who would speak in such an unorthodox manner.

Some fifteen additional poems that imitate the Belle Dame or the trial poems also are collected in

I2. A Cour Amoureuse was established at Charles VI's court on St. Valentine's Day in I40o, purportedly to please and entertain Queen Isabeau. The Cour Amoureuse's mission was to anthropomorphize the allegorical courts of Love of courtly literature in order to glorify the loyalty and humility of ladies of the court while cultivating the art of poetry. A charter listed the association's organization and functions, including a list of adherents, some with their coat of arms and official responsibilities and poetic puys were organized (Bozzolo et al. I982-92). The court was increasingly influenced by Burgundians. After I4I9, the Burgundians and Charles VII's retinue, including Alain Chartier, were engaged in active civil war, suggesting that it would have been some other love court at play here, if any.

I3. In a marginal note of one of the manuscripts containing the Lai de Guerre, Vatican, Regina Lat. I683 is written “est assavoir que Nesson, estant le roy à Issoudun, trova une crie de la ville faisant ung cry de par le Roy et estoit ladicte crie yvre. Si fist Nesson banner maistre Alain, par moquerie, par tous les carrefours. Et de ce parle Guerre en ce lieu”. Chartier also poked fun at Nesson, for example, in the concluding lines of the Debat du Herault, du Vassault et du Villain (Laidlaw 1974: 42I-35).

I4. Fribourg, bibliothèque cantonale et universitaire Ms L i2Oo. Editions of the trial poems are found in McRae 2004 and Piaget I9OI-I9O5. 
these and other manuscripts. ${ }^{15}$ In some of the texts the lover's plight is presented, in others the lady's rights in love are featured. At issue in many of these imitation poems are the author's responsibility for the effect his work will have on readers, the rights of women in love, and the reputation of women. These themes reiterate those brought forward by Christine de Pizan and Jean Gerson in the debate over the Roman de la Rose. That Chartier would wish to highlight such timely and pertinent issues is not surprising, given how frequently he undertakes issues first introduced by Christine. Indeed, modern critics localize the origins of the querelle des femmes in the works of Christine. ${ }^{16}$

Chartier's name became an authority to invoke in advocating for the rights of women. The campaign to champion women spread widely from the middle of the fifteenth century through the Renaissance. Martin Le Franc featured Chartier as a staunch defender of ladies in his Champion des dames, ${ }^{17}$ in which the final sentence of the cruelle femme was rejected in favor of the outcome of the loyalle dame. Martial d'Auvergne revisited the trial in the twenty-fifth episode of his Arrêts d'amour, resurrecting the drowned lady to allow a more appropriate sentence for her rejection of the amorous mores of her time: retreat from courtly life into a reclusive religious community; while the Lover is encouraged to find a new paramour. In the sixteenth century, beyond Anne de Graville's Rondeaux, Chartier and his Belle Dame were invoked in Marguerite de Navarre's Heptameron. Marguerite, whom Anne attended after I529, ${ }^{18}$ twice demonstrated through her character Parlemente how the belle dame's words can advise young ladies against the dangers of courtly rhetoric and feigned lovesickness used by men to seduce them: "La Belle dame sans mercy nous a apprins à dire que si gratieuse malladye ne mect guere de gens à mort" in nouvelle XX and again in nouvelle LVI: "Mais la Belle Dame sans Mercy respond qu'il siet bien que l'on le die, pour en tier quelque confort". ${ }^{9}$ Parlement refers to Alain as an authority, while her interlocutor Simontaut refers to him in sarcasm as the "notable docteur" whose lady did nothing to heal lovesickness. Through the discussion over the validity of courtly love language and the true meaning of "merci", the characters resurrect the issues of the Belle Dame quarrel - the rights of women in love and the nature of language and speaking the truth - while proving the enduring influence of the Belle Dame and the Quarrel it inspired. ${ }^{20}$ Marguerite de Navarre avers her admiration of Alain Chartier in several other works that imitate Chartier, La Coche, whose subject is "digne d'un Alain Charretier" and Les Quatre Dames et les quatre gentilshommes, whose title was inspired by Alain's Livre des quatre dames (Montmorand I9I7: I2I). Anne de Graville thus is not the only courtly personage interested in Alain Chartier and the Belle Dame sans mercy. The influence of this author and the impact made by his most redoubtable character attracted the keen attention of these courtly ladies. But her translation of the poem into rondeaux received little attention until the end of the $19^{\text {th }}$ century when Swedish scholar Carl Wahlund rediscovered the manuscript of Anne's Rondeaux and was able, by means of her anagram "J'en garde un leal” (f. Ir), to attribute the poems to her. He subsequently produced the first modern edition of the Rondeaux, published in I897.

I5. For editions of some of these poems, see McRae (2004) and Piaget (I9OI-I9O5).

I6. Anne Paupert says, "Le rôle de Christine de Pizan dans les débuts de la Querelle des femmes est généralement bien reconnu dans les etudes récentes sur ce sujet...” (20I3: 23-37).

I7. Chartier and his character the belle dame are lauded by Martin Le Franc in Le Champion des Dames (Deschaux ed. г999: vv. I903-04, I907-08, г92I-22; г2585-6, I4639-40,I8965-6).

I8. “The name 'Antraigues' (a variant spelling) is listed under 'Dames et Demoiselles' in Margaret of Navarre's household for the year I529 (Paris, Ste-Geneviève, ms. 848, ff. I63-64)" (L'Estrange, forthcoming monograph, introduction).

I9. Both allusions refer to Chartier vv. 265-68: "Sy gracïeuse maladie / Ne met gueres de gens a mort / Mais il chiet bien que l'on le die / Pour plus tost attraire confort".

20. See Frelick 20Iо: $325-36$ and Bouchet 20I5: 332-33. 


\section{Wahlund's Edition of the Rondeaux}

As mentioned earlier, copied in the margin of $\mathrm{BN}$ fr. 2253 that contains the Rondeaux are Chartier's verses, the better to compare the original poem to Anne's adaptation. In his edition of the Rondeaux, Wahlund, disturbed by a few points of departure in the wording of the rondeaux and that of Chartier's verses, replaced the marginal verses of the original manuscript, BN fr. 2253 , with the reading of an early printed edition which he deems closer to Anne's translation, explaining this editorial decision in the introduction, here translated from the Swedish: "The version of Chartier's poem published here is based on a rare, undated, roughly 400 -year-old printed text from the National Library in Paris (Y. 6I56. B. 2; Inv. Réserve Ye 838)" (I897: 3-4). His justification for making this alteration was to try and identify the copy on which Anne based her translation: "The important thing here was not to take the text that was closest to the version that Alain Chartier actually wrote down, but one that was, as far as possible, most like the one on which Anne de Graville based her adaptation" ${ }^{21}$ In addition to replacing the marginal verses with the reading of Ye 838 (c. I489-90), Wahlund identifies similarities with another printed copy: BN, Rothschild 443 [IV , 4, 85] (c. I5OO). He thus replaced the entire marginal reading of the original manuscript with the reading of an external source with variant readings not to the original text, but to the Rothschild incunable. The replacement renders his edition unreliable, since his edited version does not present the readings of the manuscript. Instead the edited presentation obscures the reading copied into Anne's manuscript, the most obvious version to have been used in the production of her Rondeaux.

A second editorial decision Wahlund made equally complicates a modern reader's appreciation for the poem as presented in BN fr. 2253. On I2V-I3r the scribe copies two of Chartier's verses on the folio's verso, thus rendering the previously parallel construction, one octave to its translated rondeau, now uneven. The scribe anticipates this, and signals it with a red rubric: "pour le rondeau d'apres", indicating that the marginal verse corresponds to Anne's rondeau on the subsequent page. The facing recto, I3r., is copied by a second scribe, whose ductus and morphology distinguish his work most notably by more elaborate letter construction and pen flourishes. Did this second scribe make an error? Perhaps. But if so, it would have been easy to rectify since the central text was copied before inserting Chartier's verses in the margin. No attempt to correct the arrangement was made. We must conclude, therefore, that the change was deliberate. For the remainder of the manuscript, after I2V-I3r, the marginal octave consistently serves as a precursor to the rondeau that follows on the next page. The reader is repeatedly reminded of this order on each folio by the red-lettered "pour le rondeau d'apres".

The marginal indicator "pour le rondeau d'apres" also instructs readers to address the text according to the hierarchy of glossed academic or religious text: read the larger, central verses first, then the smaller writing in the margin. Such a procedure sets up a dynamic dialogue between Alain and Anne that propels the narration forward, prompting the lady to respond to the lover, or the lover to the lady, Alain's lover to Anne's lady, then Anne's lover to Alain's lady. Before this transition, each folio was pitting Anne's lady against Alain's lady, or Alain's lover against Anne's lover, inspiring quite a different dialogue than the lover vs lady intended by the authors. At f. I2v, however, through the altered format, Anne is able to insert her voice actively in the debate, responding to Alain in her own larger space. Wahlund, by shifting the verses forward to reestablish the original parallel structure of the page, realigns the verses so that Anne's lady echoes Alain's lady and her lover echoes Alain's lover. Wahlund thus alters the dynamic of the dialogue that had been deliberately adjusted by

2I. The Swedish translation of the introduction of Wahlund's edition was elicited by Elizabeth L'Estrange from Vicki Brett, who translated it; Charlotta Nordstrom double-checked it for nuance and precision. 
Anne and her scribes. Critics, too, have thus far been influenced by Wahlund's editorial decision, basing their commentary on the translation of character and voice rather than the dialogue that Anne is performing with Alain's verse. There is more to be said on this issue, but it is beyond the purview of the current study.

\section{Manuscripts in Anne de Graville’s Milieu}

$\mathrm{W}_{\mathrm{a}}$ ahlund's editorial decision aside, it is not certain that Anne's source was a printed copy. Why replace the version written into her margin? Its readings are too frequently disparate from the incunables Ye 838 or BN or Rothschild 443 [IV, 4, 85] for either to have been her source. Ye $83^{8}$, the incunable chosen by Wahlund, appears to be based on Grenoble, bibliothèque municipal $874 .{ }^{22}$ It demonstrates over thirty unique readings. Only three times do its readings correspond with BN fr. 2253 against the common manuscript reading: at line 240 "scet mal" for "sent mal"; verse 417 "requiers" for "quiers" (however, in Anne's rondeau version f. r6r, "requiers" is used); and at verse 626 "celez" is used instead of "seellees" and is confirmed in the rondeau on f. 29r. So why did Wahlund replace Anne's marginal readings? Why did he not seek her source in a manuscript? Wahlund, working in the late nineteenth century, had limited access to the forty-five manuscript copies we have identified today of the original poem. Nor did he have access to a modern critical edition of the Belle Dame sans mercy. ${ }^{23}$ Today we do not face these same constraints, a situation which permits us to search again for the real source of the marginal reading.

A bit of sleuthing into the provenances of extant Chartier manuscripts reveals four containing the Belle Dame sans mercy to which Anne likely had access. The first is BN fr. 20026, a manuscript made for Marie de Clèves, mother of Louis XII whose books were subsumed into the royal library at Blois, accompanied by its pendant copy made for Marie's sister-in-law Marguerite de Rohan: BN fr. 2230. The third manuscript is BN fr. 924, owned by Jacques Thiboust, lord of Quantilly, and close associate with the royal family. The last is St. Petersburg, MS fr. ${ }^{\circ}$ v. XIV. oooz. While Anne may well have had access to other Belle Dame manuscripts or printed books, these four manuscripts were the most probable references for her.

\section{I Bibliothèque nationale, français 20026 and its pendant $B N$ fr. 2230}

While in residence with the Queen at the royal château of Blois, Anne could have had access to the royal family's library. In this collection was a manuscript created sometime after I 440 for Marie de Clèves, third wife of Charles d'Orléans, now held in Paris, B.N. fr. 20026. ${ }^{24}$ The manuscript contains Chartier's Belle Dame, the letters, Excusation and what may be an early version of the first trial poem, Les Accusations contre la belle dame sans merci. ${ }^{25}$ Its fly-leaves are animated with signatures and mottos of family, household members, neighbors, and visitors, presumably readers,

22. Grenoble, bibliothèque municipal, 874 is mid-I $5{ }^{\text {th }}$ century manuscript containing the Belle Dame and many of Chartier's ballads and rondeaux; it is devoid of any markings to indicate previous possessors (Laidlaw I974: 8I-83).

23. See the Laidlaw 1974 and McRae 2004 descriptions of the forty-four manuscripts, in addition to the newly discovered Hatfield House manuscript (McRae 20I8) and rediscovery of the Clumber Park manuscript in 2015 (Christie's 20I5).

24. Descriptions of BN fr. 20O26 can be found in McRae 2OO4: 28-3O; Laidlaw I974: III-II2; and Taylor 2OIO: I3-29.

25. The version is truncated at line 560 , after the prosecuting attorneys have pronounced their judgment and punishment (McRae 2004: I4, I67, and note 24). 
which serve as evidence of early discussions of the Belle Dame quarrel (McRae 2004: 28-30; Laidlaw 1974: III-II2; Taylor 20IO: I3-29). The codex was passed from Marie to her son who would become Louis XII - it is included in the inventory after her death in $\mathrm{I}_{4} 87$, and his signature appears on a fly-leaf. Louis XII married Anne of Brittany in I 499 and their daughter Claude was born that same year. Anne died in Blois in I5I4; Louis XII passed in I5I5. It is presumed that Claude inherited the library of her parents (Champion I9IO: 323 , footnote) including the manuscript containing the Belle Dame that Louis XII had inherited from his mother, Marie de Clèves. ${ }^{26}$

Both the parallel manuscript readings and item arrangement indicate that a second manuscript, B.N. fr. 2230 was copied from Marie de Clèves's manuscript for her sister-in-law Marguerite de Rohan, married to Jean d'Angoulême in I 445 after his release from English captivity. Additional texts, including the Hospital d'Amours by Achilles Caulier and the Débat des deux soeurs by Jean Vaillant suggest that the manuscript was copied after I 450. The fly-leaves are decorated with signatures and devices; some repeat those in inscribed in Marie's manuscript. The impaled arms of Angouleme and Rohan as well as the initials J and M intertwined with rope identify the manuscript as Marguerite's (McRae 2004: 30-32; Laidlaw 1974: Io8-o9). Marguerite and Jean's son Charles would father François I. The couple's great collection of books was thus incorporated into the royal library through François I's inheritance. The Chartier manuscript does not appear in the royal library's catalogues until the Rigault catalogue made in I622, no. 23IO, "Loy de paix et d'amitié, debat de bien et de mal d'amours, et jugement d'amours, en vers francois", inscribed as MMCCCX (Omont: I908-2I, 2: 377). Both of these manuscripts have been judged as "poor" copies because of their individual readings that depart from lessons of other manuscripts (Laidlaw i974: 56, Io9).

\subsection{Bibliothèque nationale, français 924}

Like the literary salon formed by Charles d'Orleans and his wife Marie de Clèves at Blois, Jacques Thiboust, lord of Quantilly and his wife Jeanne de la Font formed a literary salon in Bourges in the I520s under the auspices of Marguerite de Navarre (then Marguerite d'Angoulême), herself a magnet for literary-minded nobles. Marguerite arranged the marriage between her private secretary and Jeanne and together they were able to cultivate the study of the arts and support the pursuit of scientific knowledge at their chateau in Quantilly. Influential poets of the day, including Clément Marot and François Habert, spoke of their château as a "paradise on earth". Although none of her poetry survives today, Jeanne was widely recognized as a muse and a poet. The epitaph that laments her untimely death praises her adaptation of Boccaccio’s Teseida into French, claiming it rivals both Latin and Greek in its eloquence: "Oh! Que la France te lise! Elle verra dans ton oeuvre ce que fut la puissance latine, et sous quelles ruines dorment splendeurs de la Grèce” (Epitaphe de Jean Second, translated in Boyer I859: I8). ${ }^{27}$

This gracious court flourished alongside that of Marguerite de Navarre where Anne was in service after I529. Anne must have been an avid admirer of this paradise on earth in Bourges; her literary interests ran in parallel with Jeanne de la Font as both of them were poets and produced French adaptations of Boccaccio's Teseida. Though we have no direct evidence of correspondence between Anne and Jeanne, they would have frequented Marguerite's court around the same time, from I529 until Jeanne’s death in I532. Anne might also have been interested in a manuscript owned

26. Marie's manuscript is not included in the list of the $\mathrm{I}^{\mathrm{I}} \mathrm{8}$ inventory of the Blois library as reported by Salda, but he does suggest that additional manuscripts were held in the royal family's "personal collections" (I994: 22 note I). For a history of Marie’s bibliophilia, Müller 200I: 57-76.

27. See Müller 2004. 
by Jeanne's husband, Jacques: BN fr. 924, a late $15^{\text {th }}$ century paper codex and one of the most complete copies of the Quarrel of the Belle Dame extant today. Moreover, its owner's thoughts are captured in frequent marginal notations and corrections (Piaget ro96; McRae r997: 383-86; McRae 2004: 35-37; Laidlaw I974: IOI-IO3). For example, on folio 39v, at the termination the first Belle Dame trial poem, Thiboust confirms: "Explicit, Nous serons contre la belle dame sans mercy". Frequent marks such as a cross or an asterisk mark passages in the Belle Dame sans mercy, accentuating the importance and influence of these passages to their reader. These include $v$. I7O: "Car qui plus est pres pus desire" which is marked with an asterisk and a "nota"; v. 238: "Les yeulx sont faiz pour regarder", marked with an asterisk; v. 240, originally written "Qui y sent mal, s'en doit garder" corrected by Thiboust to read "Qui mal y sent s'en doit garder", vv. 27I-72: "Et s'amour grieve tant, au fort / Mieulx en vault ung dolent que deux". We should note, too, that these last verses terminate the stanza that begins with the famous "Si gracïeuse maladie / ne met gaires de gens a mort" (vv. 265-66) cited by Marguerite de Navarre's Palemente. Thiboust has altered the verse to read "Si Amoureuse maladie". These markings imply that the manuscript may have served as a resource for the discussions of the Belle Dame quarrel that happened at Marguerite's court, which Thiboust, as Marguerite's secretary, would likely have attended accompanied by his erudite bride Jeanne de la Font. Anne de Graville, as one of the ladies of Marguerite's court, would have also participated. It may have been in these circumstances that Thiboust marked the lines that later would be incorporated into the nouvelles of the Heptameron. After Thiboust and his companions read the Belle Dame sans mercy from this manuscript, they likely progressed to read the rest of the Quarrel, both the trial poems and imitation poems copied into the manuscript.

\section{$5 \cdot 3$ St. Petersburg, National Library of Russia MS fr. ${ }^{\circ}$ v. XIV. ooo7}

No contemporary or modern inventories or descriptions of the de Graville library include a Belle Dame manuscript. However, there is a codex held today in the National Library of Russia in St. Petersburg, MS fr. ${ }^{\circ}$ v. XIV. ooo 7 that may be significant to our investigation. Several signatures and mottos appearing on the fly-leaves indicate it may have belonged to Anne de Graville's family. On the inside front cover is the signature "Francoys Martel" followed by the signature "de Bacqueville" on folio I54v. In addition, on folio Ir we see the motto "Au besoing, Maulevrier"; this is the motto of Jacques de Brézé, noted in the manuscript description of the Institut de Recherches et d'Histoire des Textes (IRHT) in Paris. Jacques may have inherited the book from his father, Pierre de Brézé, also lord of Maulevrier and close associate of Charles VII ${ }^{28}$ or acquired it from Louis de Beaumont-Bressuire (d. I477), whose signature and motto appear just below: "Foy sans esperance Loys de Beaumont", a nobleman also in the service of Charles VII and Louis XI and made knight of the Order of St Michael in I 469. Jacques de Brézé was condemned in I 477 for the murder of his wife, Charlotte de Valois, half-brother to Louis XI through Agnès Sorel, his father Charles VII's mistress, whom he caught en flagrant délit with her lover. Upon his condemnation, his possessions were seized by the king. Perhaps Louis XI gave Louis Malet de Graville this book, as he did with some of the books confiscated from Jacques d'Armagnac, ${ }^{29}$ a scenario which would explain the preposition

28. Another possibility is that the manuscript passed from Jacques de Brézé to his son Louis de Brézé, since the property confiscated by the king was largely restored to Louis. Louis married Diane de Poitiers who was also dame d'honneur for Queen Claude and then Louise de Savoie. She was at the court at the same time as Anne and may have brought the manuscript with her. This scenario, however, does not adequately explain the other signatures in the manuscript.

29. Apparently, after assuring the condemnation of Jacques d'Armagnac, Louis Malet de Graville was given a portion 
included in the inscription in the upper margin on the following leaf, folio $2 \mathrm{r}$ : "Pour mons(eigneur) de Marcousys", presumably Louis Malet de Graville. According to L’Estrange, two additional manuscripts belonging to Graville have similar inscriptions written in the same hand. $3^{\circ}$ Did Louis XI give the book, confiscated from his condemned brother-in-law, to Graville, such that the "pour mons(eigneur) de Marcousys" indicates that the book was put aside for him? Did a bookseller write those words to reserve a purchase for the Admiral? Or, there is a second potential line of possession. Jean Malet de Graville, Louis de Graville’s father, married again after the death of Louis's mother. His second wife was Marie de Monberon, daughter of François de Montberon and of Maulevrier (d. I470) and granddaughter of Marie, baronne de Maulevrier d. I4O7. This second marriage produced a daughter, Renée, Louis’s half-sister, who married Jean Martel, Seigneur de Bacqueville. They produced an heir, François Martel, seigneur de Bacqueville. Did Louis inherit the book from his father, who subsumed the book into his collection affording access to Anne who perhaps then inherited it, and passed it on to her children? A Charles Martel de Bacqueville, married to Anne's eldest daughter, was given charge of the children still of a minor age after I53I (Montmorand I9I7: 99). $\cdot{ }^{3 \mathrm{r}}$ One further connection that links this manuscript to the Graville library is the presence on the cover leaf of a scribbled poem by François Villon, "Ballade des langues ennuyeuses" that also appears in the Rohan Chansonnier, Berlin, Staatliche Museen Preubischer Kulturbesitz, Kupferstichkabinett MS 78.B.I7 made for Louis de Graville sometime shortly before I470 and later inherited by Anne. More than twenty of Chartier's lyric verses also appear in the Rohan. So, although it remains unclear just how the book entered the family library, the family signatures assure us that indeed this book at some point was in the family's collection. Moreover, the signatures and mottos, pen marks and added verses, some of which date to the early sixteenth century, demonstrate that it, like Marie de Clèves's manuscript, may have served as a kind of conversation prompt for discussion of the Belle Dame quarrel..$^{2}$

St. Petersburg, National Library of Russia, MS fr. $f^{\circ}$ v. XIV. ooo 7 is a parchment manuscript of I78 folia produced in the mid-fifteenth century, decorated with initial letters of red and blue. It is written in a cursive hand, perhaps once easily readable, but now the ink has bled through the thinner parchment rendering it difficult to decipher at certain points (Laidlaw I974: I30-3I). It is one of the more complete compendia of the Belle Dame Quarrel, including the Belle Dame sans mercy, several related works of Alain Chartier, and the first three trial poems. The items it contains are detailed in Olivier Delsaux's description (2OI4: 3-7); briefly, it presents a table of contents (f. 2); Chartier, Le Debat des quatre dames (3r-65v); Chartier, La Complainte maistre Alain (66r-69r); Chartier, La Belle Dame sans mercy $(69 \mathrm{v}-85 \mathrm{v})$; the letters of the ladies and the courtiers $\left(85^{\mathrm{v}-87 \mathrm{r}}\right)$; Chartier, Excusacion de maistre Alain (87r-92r); Anonymous, Les XII Vertus de noble homme (92r-96v); Anonymous, balades, virelay, rondel (95r-97v); Achille Caulier, La Cruelle Dame en amour (98r-II4v); Anonymous, Le Jugement comme la dame qu'on disoit sans mercy fut trouvee loyale en amour (II4V-I32v); Baudet Herenc, Le Procés de la dame dont elle demanda estat et delay (I33r-I44r; Chartier, Le Breviaire des nobles (I44V-I52v); Michault Taillevent, Le Saultier des villains (I53r-I60v); Anonymous, Le Debat du nouveau marié (I6Ir-I68v); Chartier, Le Reveille matin (I69r-I76r). The scribe, in addition to employing forms common in north-eastern France as Laidlaw attests (I3I), such as s'efforchoit (v. 89), s'enlachoit (v. 94) or calenge (v. 205) also demonstrates

of Jacques d'Armagnac's rich collection of books by Louis XI (Longeon I975: I5I and note I4).

3o. One of these manuscripts is additionally linked to Louis by the inclusion of his arms: Ste-Geneviève, MS II44,

Policraticus; another is likely to have belonged to either him or Anne, based on the inscription: Paris, Arsenal, ms 52IO,

Roman de la Rose (L'Estrange forthcoming: Chapter I).

3I. Source: L'Estrange, in private correspondence with this author.

32. See Delsaux for transcriptions of all of the non-scribal additions. 
occasional synonymic substitutions, such as copying me for mais (v. 7o6), cun for qu'un (v. 692), celez for seellees (626); ce non for ce nom (v. 554); n'ai ge for n'ay je (527). The scribe also commits from time to time the error of dittography, for example, copying "le lieu" for "le ieu" (v. 495). The readings it presents are often similar to another manuscript, BN fr. II3I, also a mid-fifteenth century parchment manuscript that demonstrates north-eastern forms, but which has no annotations to indicate previous owners. ${ }^{33}$

\section{Variant Readings and Conscious Interventions}

A Anne, who in I5I8 inherited a large portion of her parents' library, likely had easiest access to the St. Petersburg manuscript, assuming it was in her family's library. This prompts us to make a close comparison of readings between it and Anne's marginal readings to ascertain if indeed it served as Anne's 'base' manuscript. Access to the St. Petersburg manuscript is available through an old I95Os microfilm held at the IRHT in Paris. A close comparison of the version presented in the St. Petersburg manuscript to the marginal text of Anne's manuscript reveals many similarities, with some dissimilarities. The parallel readings indicate that indeed Anne had access to this manuscript and may have used it as her base text. Readings that diverge from the St. Petersburg manuscript, however, suggest that Anne, in writing her rondeaux, consulted more than one manuscript, and perhaps a printed edition or two as Wahlund suggested. Moreover, in some instances the reading in Anne's manuscript is unique: it is possible that Anne changed the verses in her base manuscript(s) to improve on them. Anne was a poet. In rewriting to create her adaptation, she was keenly aware of the semantic needs of her own composition. Occasional emendations to the readings of Chartier's verses in the margin prompt us to consider if these changes were made by scribes or Anne herself. It is possible that they were made by Anne. Christine Reno noticed a similar phenomenon with regard to Anne's two copies of Christine de Pizan's Mutacion de Fortune, Bayerische Staatsbibliothek, cod. Gall. II, an early fifteenth century parchment manuscript and Paris, Arsenal 3I72, a paper copy likely commissioned by Anne. Reno reveals that Anne is an "intent and even inventive reader of Christine" (1998: I77): in a hand that is likely Anne’s, missing verses are inserted with readings derived from other manuscripts, some variant readings are corrected to the standard version offered in other manuscripts, and many other interpolations give unique readings (Reno I998: I78-I82). Anne not only corrects her text when it is faulty, but she also does not hesitate to improve that text where necessary. Reno concludes, "These verses suggest that Anne's creative impulses and her desire for a complete text won out over scholarly scruples, and that she did not shy away from filling in Christine's text when this appeared necessary" (I998: I8I-2). In these Christine de Pizan manuscripts, Anne, clearly a discerning reader of manuscripts, acted as scribe, editor, and author as she established a text that best suited her needs. Reno even identifies in the corrections a hand that she identifies as Anne's. ${ }^{34}$ Is it unreasonable to expect that she would willingly do the same with regard to the production of a manuscript containing her own rondeaux? She was certainly not hesitant to alter the structure of Chartier's text. Not only did she translate the verse form into a more popular poetic form, she also eliminated the introductory framework in which the author/narrator had introduced himself and his context, further removing the identification of her verses with

33. BN fr. II3I was used as the base manuscript for the Hult and McRae critical edition of the Quarrel poems because it a reliable and easy to read text. Description of manuscript (Hult et al ed. 2003; Laidlaw 1974: IO3-IO4).

34. There are also corrections made by two hands in the St. Petersburg manuscript; the first surely belongs to the scribe. Unfortunately, the quality of the reproduction is not clear enough to analyze the second hand. 
Maistre Alain. Similarly, in the Palamon and Arcita, Anne excised Boccaccio's lengthy account of the conquest of the Amazons, compressing it into a mere sixteen verses (Reno I998: 182). What she wished to emphasize and expand upon, in both of her literary creations, was the social interaction of women locked in a man's world.

As we consider which manuscript might have served as her base manuscript for the reading found in BN fr. 2253, we should keep in mind her predilection for culling manuscript readings and expect that she will alter that base manuscript where necessary and even invent readings to ameliorate her text. The lessons gleaned from the Christine de Pizan manuscripts may offer us explanations with regard to the Belle Dame sans mercy and Anne's translation of it into rondeaux. Although we cannot know with certainty if decisions are made by Anne herself or her scribes, we can expect that she may well have supervised the production of the manuscript and exercised an author privilege over the both texts in question.

Anne's manuscript generally adheres to the readings of the Saint Petersburg manuscript. ${ }^{35}$ On many folia the stanza in the Saint Petersburg manuscript is almost identical to Anne's manuscript reading, for example, on folia IIr, I8v, 2Or, $24 \mathrm{r}, 27 \mathrm{r}$, 27v, and $3 \mathrm{Ir}$; the stanza copied on $20 \mathrm{Or}$ as transcribed appears almost exactly as the St. Petersburg manuscript with no alterations - even a necessary hiatus, altered in other cases in Anne's version, is maintained for the syllable count "ouÿr" (v. 489) and its rhyme "esioÿr" (v. 49I).

\section{St. PetersburG}

Se mon conseil voulez ouÿr

Querez ailleurs plus belle et gente

Qui d'amours se veulle esiouÿr

Et mieulx sortisse a vostre entente

Trop loing de confort se tourmente

Qui a par soy pour deux se trouble

Et celui pert le l ieu d'attente

Qui ne scet faire son point double

$$
\text { (vv 489-496) }
$$

BN FR. 2253 (ANNE)

Se mon conseil voulez ouÿr Querez ailleurs plus belle et gente Qui d'amours se vueille esiö̈r Et myeulx sortisse a vostre attente Trop loing de confort se tormente Qui a par soy pour deux se trouble Et celluy pert le ieu d'attente Qui ne scait faire son point double

The stability of the stanzas suggests that the St. Petersburg manuscript was used as exemplar.

The incunable chosen by Wahlund, which appears to be based on Grenoble, bibliothèque municipale $874^{36}$ demonstrates over thirty unique readings. Only three times do its readings correspond with $\mathrm{BN}$ fr. 2253 against the common reading: at line $24 \mathrm{O}$ "scet mal" for "sent mal"; verse $4 \mathrm{I} 7$ "requiers" for "quiers" (however, in Anne's rondeau version f. I6r, "requiers" is used); and at verse 626 "celez" is used instead of "seellees" and is confirmed in the rondeau on f. 29 r.

On the other hand, the St. Petersburg manuscript counts eighteen unique readings, thirteen of which have correspondence in either BN fr. II3I, Thiboust's manuscript, or the Marie de Clèves/ Rohan manuscripts. Only five of the lessons are truly unique.

Ideally, we would seek a common reading unique to the two texts to prove that one has been copied from the other. Integration of the change within Anne's rondeau would confirm the link.

35. To simplify, I reference Anne's marginal copy of Alain's poem, as well as the readings of other manuscripts, by the verse number of the Belle dame sans mercy, keeping in mind, however, that Anne's version of the poem begins at verse 193. To refer to Anne's rondeaux, I reference the folio of BN fr. 2253.

36. Grenoble, bibliothèque municipal, 874 is $\mathrm{mid} I 5^{\text {th }}$ century manuscript containing the Belle dame and many of Chartier's ballads and rondeaux; it is devoid of any markings to indicate previous possessors (Laidlaw I974: 8I-83). 
Unfortunately, there is not a single instance in which we see the triple coincidence of readings only in St. Petersburg, BN fr. 2253, and the rondeau.

However, twice we have corresponding readings between BN fr. 2253 and the St. Petersburg manuscript. At verse 328, St. Petersburg and BN fr. 2253 both read "acquis" at the rhyme, along with BN fr. II3I and two additional manuscripts ${ }^{37}$ against the common reading of "conquis"; however, "acquis" does not appear in Anne's rondeau on f. Ior. A second reading shared between the two manuscripts, as well as by BN fr. II3I, is at verse 729: "Quant meschans mechant parler usent”. Laidlaw rejects this variant reading out of hand, calling it impossible (I974: 33I note I), preferring the reading of his base manuscript, Toulouse bib. mun. 826: "Quant meschans fol parler eüssent". The reading from Marie de Clèves's manuscript, BN fr. 20026, "Quant meschans meschant parler eussent", is quite similar to both Anne's reading and the Saint Petersburg manuscript: revealing a possible link between these three manuscripts.

Occasionally, there are significant differences between the readings of BN fr. 2253 and Saint Petersburg. We might, however, attribute these differences to Anne and/or her scribes' particular sense of how a verse should look and sound. As anticipated given Anne's inclination as a poet and editor, the marginal text of $\mathrm{BN}$ fr. 2253 presents twenty-nine unique readings, that is, readings that are not attested in any other Belle dame copy, thirteen of which are confirmed in the corresponding rondeaux. Twice the change of reading is reversed in the rondeau (verse $7 \mathrm{O} 2$ and f. 33v; verse 66I and f. 3 rr) back to the common manuscript reading.

Some stanzas are reworked more than others: the later portion of stanza I8r, for example, is extensively revised from the Saint Petersburg model:

\section{St. Petersburg}

A vostre honneur seul entendez

Pour vostre honneur mieulx employer

Du mien a moy vous attendez

Sans prendre paine a foloyer

Bon fait craindre et a supployer

Ung cuer folement deceü

Car rompre vault pis que ployer

Et esbranlé mieulx que cheü
BN FR. 2253 (ANNE)

A vostre honneur seul entendez

Pour votre temps myeulx employer

Du myen a moy vous attendez

Sans prendre poine a folier

Il fait bon vaincre et supployer

Ung cueur trop follement deceu

Car rompre vault mains que ployer

Et esbranler myeulx que estre cheu

$$
\text { (vV. 457-464) }
$$

Analysis of these changes reveals where Anne or her scribe has corrected scribal error or re-written Chartier's verses. In verse 458, for example, the scribe of St. Petersburg miscopies "honneur”, eye-skipping from the previous verse that featured this word in mid-verse (a unique reading arising from this scribal error), but Anne/scribe corrects it in BN fr. 2253. In v. 46I "Bon fait craindre et a supployer" (a non-standard reading also found in BN fr. II3I) the text is reconfigured in BN fr 2253 to replace "bon fait" with "il fait bon" as well as to correct "craindre" with the common reading "vaincre". Likewise, verse 462 is rewritten to eliminate the hiatus in the final rhyming word seen in Saint Petersburg and other manuscripts: “Ung cuer folement deceü” is changed in BN fr. 2253

37. The other two manuscripts are Laidlaw’s $G f:$ New York, Pierpoint Morgan Library 396 , an early $5^{\text {th }}$ century manuscript that is related to BN fr ІІ3г and St. Petersburg, similarly employing northeastern forms (Laidlaw I974: 73). Ph (Laidlaw I974: IIO-III) is BN fr. I9I39 a near 5 Oo folia compilation of works of Chartier and Charles d’Orléans. Its often unique lessons show reader markings that correct readings from another exemplar, likely an early printed copy, but there is no indication that it was in the royal library at Blois. 
to read "Ung cueur trop follement deceu". $3^{8}$ Jacques Thiboust, too, in his own hand corrects this verse in BN fr. 924 twice, first adding "trop" as Anne did, and then canceling 'trop' and adding "qui est" in superscript: "Un cueur qui est follement deceu". In verse 463 , Anne or her scribe alters the common manuscript lesson of "pis", to "mains"; and finally, in verse 464 , to eliminate the hiatus of the general manuscript lesson "cheü" another word must added: "estre", altering her text from the general manuscript lesson "Et esbranlé mieulx que cheü" to "Et esbranler myeulx que estre cheu". Thiboust, too, revises his manuscript's reading in a similar fashion: "Et esbranlé que d'estre cheu".

Another distinctive and unique reading of BN fr. 2253 is found at verse 574. Anne's text reads "Qu'avoir fait bien tost empirer" which accords with the general manuscript lesson, including Thiboust's. However, in St. Petersburg, "avoir" is replaced by "amour”. Only the Marie de Clèves/ Rohan manuscripts, and BN fr. II3I also follow this reading: "Qu'amours font bien tost empirer". Anne's version at this point does not follow St. Petersburg, or the Clèves/Rohan exemplar, but has apparently been corrected with the help of perhaps Thiboust's manuscript, an early modern printed text such as the one Wahlund identified, or perhaps yet another manuscript.

\section{${ }_{7}$ Conclusion}

Comparing manuscripts is an arduous and tricky business. Which variants are the result of scribal error or negligence? Which are regional or orthographic variations? Which are semantically relevant? And yet, following the mouvance of a text can whisper clues to a modern reader about how a work was copied, disseminated, even interpreted. The few examples outlined above suggest that Anne was supplementing her exemplar with variants and corrections from additional manuscripts and printed editions. That exemplar was very likely the manuscript that carries multiple signatures from Anne de Graville’s family, Saint Petersburg, National Library of Russia, MS fr. f $^{\circ}$ v. XIV. ooo7; the variant readings and corrections often come from Marie de Clèves' manuscript, BN fr. 20026, and her sister-in-law's Marguerite de Rohan’s pendant manuscript BN fr. 2230 and possibly from others, including the manuscript owned by Jacques Thiboust, BN fr. 924. Moreover, Anne’s manuscript offers a number of original readings that she then incorporates into her translations, her rondeaux. This process of improving the text of Chartier's Belle Dame sans mercy recalls how she was able to correct and improve on her Christine de Pizan manuscripts. When we scrutinize her manuscripts closely, we see that Anne is as discriminating and appreciative of the possibilities of mouvance, variation, and mobility as the textual theorists Zumthor, Cerquiglini, or McGann suggest that we be today (Zumthor 1972; Cerquiglini I989; McGann I983). Anne, through her intervention consciente (Cerquiglini 1989: 79), exercises her talents as an author, an editor, and a scribe in the translation of the verses into a new form, the Rondeaux.

Anne's work is "fundamentally social", just as McGann anticipates (I983: 43), and the construction of her manuscript reflects this social aspect of a text. Her presentation of the text juxtaposes her version and Chartier's version of the dialogue between lover and lady, thus reenacting the debate between the Lover and his belle dame as a debate between Anne and Alain; the organizational change at I2V-I3r serves to underscore her deliberation on this point. Through her mise-en-page, it is her Lover's voice that responds to Chartier's Belle Dame, and her Belle Dame who responds to Chartier's Lady. Her carefully contrived dialogue with Alain's text challenges the

38. Similarly, at v. 720 "Il ne doit plus estre creüz", the reading common to most manuscripts, is altered by the addition of "estre" in Anne's manuscript to read "Ne doibt pas estre tousiours creu". This change is also in the Marie de Clèves manuscript $(\mathrm{Pj})$ : “Il ne peust estre jamaiz creuz”, which might have been the source of this alteration. 
final outcome of the fifteenth century quarrel of the Belle Dame sans mercy, which condemned Alain for the creation of his cruel lady even as it punished the belle dame herself. Although Anne has almost completely eliminated the narrative frame and voice of the introduction, she slips in her own voice in the closing rondeau: "Je luy voulluz lors estre secourant / Et tout souldain je vins vers luy courant". The feminine "je" of Anne's rondeau, in wishing to comfort the distraught lover, echoes Alain's narrative voice which had empathized with the lover in the eliminated introduction: "Autel fus je comme vous estez" (v. I2O). This reinsertion of narrative voice, now a female narrative voice, reactivates sympathy for the lover, female sympathy. In fact the lady remains, even in translation, unaffected by the lover's distress: “... aucun deuil n'en a pris sa maistresse”. But now the rational refusal of the belle dame, while justified within the debate, is recast an outlier by the sympathy of the narrator.

Müller posits the interpretation that Anne softens the merciless side of the lady to render her more acceptable for the court (Müller 2003: 22). Delogu presses this interpretation further, claiming that Anne alters Chartier's verses, remodeling them "into an affirmation of women's dignity" (2OI7: 472) for her audience of courtly women. In Anne’s version, the lady's refusal is tempered with kindness, her rejection of his love is self-preservation; the love game of the court is re-calibrated on newly revised courtly terms. Anne eliminates the final two stanzas and Alain's moral, the advice of the narrator to lovers and ladies: "Si vous pri amouroux, fuiez / ces vanteurs et ces mesdisans ... Et vous dames et damoiselles... ne soiez mie si crüelles” (vv. 785-76, 793, 795),39 replacing it with sympathy: a lady (the narrator) does take pity on the lover; she rushes to help him, although to no avail. He still dies, pulling out his hair in his distress. Anne shows that she, or any female reader, can be that lady with mercy.

On the other hand, Anne also deletes the final verse of Chartier's poem, that verse oft-cited and imitated in the Quarrel poems, in which the Lady is named: "La Belle Dame sans mercy". Anne, though showing sympathy for the hapless lover, also refuses "the requalification of the Lady's chastity as "cruelty' as the poets of the Quarrel had done. In the process, she "gives leverage to the position defended by the Lady, one that asserts individuals' free will in the matters of courtly love" (Bouchard 20I8: 258, 244). The belle dame exercises that free will in her refusal to be swayed from her moral values; Anne had similarly embraced free will in choosing whom she would love and marry. Through the belle dame's words and actions are revealed the kind of power that is socially acceptable for courtly women, seen also at Queen Claude's court, that of upholding the values of Christianity, including chastity and reputation, which once lost can never be regained. Embracing both sympathy and Christian morality, Anne presents a courtly text to her patron and her audience. At the same time, she refrains from judging her characters, taking the same stance as Alain had done a century earlier. The effect of her translation is to mitigate the negative repercussions of the Quarrel on women, refuting that severity with a portrait of morality and compassion. Anne de Graville through her translation intervenes in the Quarrel of the Belle Dame sans mercy, on behalf of herself, her patron, and Alain, and thus inserts her voice into the querelle des femmes alongside Alain in the defense of ladies, for "par elles et pour elles sommes" (Excusacion v. I37).

39. Anne eliminates the first twenty-four huitains of Chartier's poem. In addition, the final two huitains, 99 and IOo, which contain the specific reference to the Belle Dame being without mercy, are left out entirely, both in Anne's translation and in the margins. 


\section{Works Cited}

Blanchard, Joël; Mühlethaler, Jean-Claude. 2002. Écriture et pouvoir à l'aube des temps modernes (Paris: Presses Universitaires de France)

Bouchet, Florence. 20I5. 'A Good Carter as Guide: Imitating Alain Chartier', in A Companion to Alain Chartier, ed. by Daisy Delogu, Joan E. McRae and Emma Cayley (Leiden: Brill), pp. 324-53

Bouchard, Mawy. 20I8. 'The Power of Reputation and Skills According to Anne de Graville: The Rondeaux and the Denunciation of Slander', in Women and Power at the French Court, 1483-1563, ed. by Susan Broomhall (Amsterdam: Amsterdam University Press), pp. $24 \mathrm{I}-262<\underline{\text { http:/ /doi. }}$ org/IO.2307/j.ctv8pzdgw.II >

Boyer, Hippolyte. I859. Un Ménage littéraire en Berry au XVIe siècle: Jacques Thiboust et Jeanne de La Font (Bourges: Impr. de la Veuve Jollet-Souchois) <https://tinyurl.com/yzpdvzou $>$

Bozzolo, Carla and Loyau, Hélène. 1982-92. La Cour amoureuse dite de Charles VI, 3 vols (Paris: Léopard d'Or)

Calin, William. 2006. 'Intertextual Play and the Game of Love: The Belle Dame sans mercy', Fifteenth Century Studies, 3I: 3I-46 <https://tinyurl.com/y4n8rzrk $>$

Cerquiglini, Bernard. I989. Éloge de la variante (Paris: Cerf)

Champion, Pierre. I9ı. 'Un liber amicorum du xve siècle: notice d'un manuscrit d'Alain Chartier ayant appartenu à Marie de Clèves', Revue des Bibliothèques, 20: $320-36$ < $\underline{\text { https: / /go.uv.es/ }}$ $\underline{\text { tqWgzpd }}>$

Champion, Pierre. 1923. Histoire poétique du quinzième siècle, vol. I (Paris: Honoré Champion)

Deldicque, Mathieu. 2019. 'La Passion des livres en heritage: Anne de Graville et sa bibliothèque', in Au Prisme du manuscript: Regards sur la literature française du Moyen Age (1300-1550), ed. by Sandra Hindman and Elliot Adam (Turnhout: Brepols), pp. Io9-I38

Delogu, Daisy. 20I7. ‘A Fair Lady Takes on Maistre Allain: Anne de Graville’s Belle Dame sans mercy', French Forum, 42.3: 47I-9I $<\underline{\text { http://doi.org/IO.I353/frf.2OI7.0044 }>}$

Delsaux, Olivier. 20I4. 'Découverte d'un témoin inédit d’une ballade de François Villon (Testament, vv I422-I456). Le manuscript Saint Pétersbourg, Bibliothèque nationale de Russie, fr. F.v. XIV.7', Le Moyen Français, 73: 3-24 <https://doi.org/I0.I484/J.LMFR.5.IO245I>

Deschaux, Robert (ed.) 1999. Martin Le Franc Le Champion des dames, 5 vols (Paris: Honoré Champion)

Frelick, Nancy. 20Io. 'Love, Mercy, and Courtly Discourse: Marguerite de Navarre Reads Alain Chartier', in Mythes à la cour, mythes pour la cour, ed. by Alain Corbellari (Genève: Droz), pp. $325^{-3} 6$

Hoffman, Edward Joseph. 1942. Alain Chartier: His Work and Reputation (New York: Wittes Press)

Hult, David, and McRae, Joan (ed.). 2003. Alain Chartier Le Cycle de 'La Belle Dame sans mercy': Une Anthologie poétique du xve siècle (BNF MS FR. 1131) (Paris: Honoré Champion)

L'Estrange, Elizabeth. 20I5. 'Un Étrange Moyen de seduction: Anne de Braville’s Chaldean Histories and her role in literary culture at the French court in the early sixteenth century', Renaissance Studies, 3.5: 708-728 <https://doi.org/IO.IIII/rest.I2I7O $>$ 
L'Estrange, Elizabeth. Forthcoming. Anne de Graville and Early Modern Book Culture in France (Suffolk: Boydell and Brewer)

Laidlaw, James. I974. The Poetical Works of Alain Chartier (Cambridge: Cambridge University Press)

Longeon, Claude. 1975. Une Province française à la Renaissance: La Vie intellectuelle en forez au xVIe siècle (Saint-Etienne: Centre d'Etudes Foréziennes)

McGann, Jerome J. 1983. A Critique of Modern Textual Criticism (Chicago: University of Chicago Press)

McRae, Joan. I997. The Trials of Chartier's 'Belle dame sans mercy'(unpublished doctoral thesis, University of Virginia)

McRae, Joan E. 2004. Alain Chartier and the Quarrel of the Belle Dame Sans Merci (New York: Routledge)

McRae, Joan E. 20I8. 'A Previously Unknown Alain Chartier Manuscript: Hatfield House, Cecil Papers 297', in Il Fist Que Proz: Essays in Honor of Robert Frances Cook, ed. by Sara Jane Miles and Stephen Martin (London: Rencesvals Publications), pp. IOI-II3

Montmorand, Maxime de. I9I7. Anne de Graville: sa famille, sa vie, son oeuvre, sa postérité (Paris: A. Picard) $<$ https://tinyurl.com/y38b7lp $>$

Müller, Catherine. 200I. 'Marie de Clèves, poétesse et mécène du Xve siècle', Le Moyen Français, 48: $57-76<$ http://doi.org/IO.I484/J.LMFR.3.62>

Müller, Catherine M. 2003. 'Anne de Graville lectrice de Maistre Allain: pour une récriture stratégique de La Belle Dame sans mercy', in Lectrices d'Ancien Régime, ed by Isabelle BrouardArends (Rennes: Presses Universitaires de Rennes) <https://doi.org/IO.4000/books. pur.35534>

Müller, Catherine. 2004. 'Jeanne de la Font et Anne de Graville, translatrices de la Théséide de Boccace au XVIe siècle', in D'une Écriture à l'autre: Les Femmes et la traduction sous l'ancien régime (Ottawa: University Press of Ottawa), pp. I87-2Io <https://doi.org/Io.2307/j. cttiww3wdo.I5>

Omont, Henri August. I9o8-2I. Anciens Inventaires et catalogues de la Bibliothèque nationale, 5 vols (Paris: E. Leroux) <https://tinyurl.com/y2w4VZxp>

Paupert, Anne. 20I3. ‘Les Débuts de la Querelle: De la Fin du XIII siècle à Christine de Pizan’, in Revisiter la 'querelle des femmes': Discours sur l'égalité/inégalité des sexes, de 1400 à 1600 , ed. by Armel Dubois-Nayt, Nicole Dufournaud and Anne Paupert (Saint-Etienne: Publications de l’University de Saint-Etienne), pp. 23-37

Piaget, Arthur. I896. 'Un Prétendu Manuscript autographe d'Alain Chartier', Romania, 25: 3I2-I5 <https://doi.org/IO.3406/roma.I896.545I >

Piaget, Arthur I9OI-I905. 'La Belle Dame sans merci et ses imitations', Romania, 30: 22-48, 317-5I' 3I: 3I5-49; 33: I79-208; 34: 375-428, 559-97 I9OI (30): 〈https://doi.org/IO.3406/roma.I9OI.5I86 $>$ I9OI (30): 〈https://doi.org/IO.3406/roma.I9OI.5204 > I9O2 (3I): 〈https://doi.org/IO.3406/roma.IgO2.5250 $>$ 
I9O4 (33): 〈https://doi.org/IO.3406/roma.I904.5339>

1905 (34): $\langle\underline{\text { https://doi.org/IO.3406/roma.I905.5416 }>}$

I9O5 (34): 〈https://doi.org/IO.3406/roma.I905.5429>

Reno, Christine. 1998. 'Anne Malet de Graville: A Sixteenth Century Collector Reads (and Writes) Christine', The Profane Arts / Les Arts profanes, 7: I70 -I82

Salda, Michael N. 1994. La Bibliothèque de François I au château de Blois (Blois: Cahiers de la Bibliothèque de Blois)

Taylor, Jane H.M. 20Iо. 'Courtly Gatherings and Poetic Games: "Coterie” Anthologies in the Late Middle Ages in France', in Book and Text in France, 1400-160o: Poetry on the Page, ed. by Adrian Armstrong and Malcolm Quainton (Aldershot: Ashgate), pp. I3-29

Wahlund, Carl (ed.) I897. Anne de Graville La Belle Dame sans mercy: En fransk dikt författad uti åtta-radiga strofer (Upsala: Almqvist \& Wiksells) <https://tinyurl.com/yxue5nzm>

Walravens, Cornelis Johannes Henricus. I97. Alain Chartier: Études biographiques, suivies de pièces justificatives, d'une description des éditions et d'une edition des ouvrages inédits (Amsterdam: Meulenhoff-Didier)

Wilson-Chevalier, Kathleen. 2OIo. 'Claude de France: In Her Mother’s Likeness, A Queen with Symbolic Clout?', in The Cultural and Political Legacy of Anne of Bretagne Negotiating Convention in Books and Documents', ed. by Cynthia Jane Brown (Cambridge: Boydell and Brewer), pp. I24-I44

Zumthor, Paul. 1972. Essai de poétique médiévale (Paris: Seuil)

\section{I Manuscripts containing works by Anne de Graville}

Chantilly, Musée Condé, I570 (Palamon et Arcita)

Paris, Bibliothèque de l’Arsenal, 5 II6 (Palamon et Arcita) < https://tinyurl.com/y695jt66 $>$

Paris, Bibliothèque nationale de France, français 1397 (Palamon et Arcita) $<\underline{\text { https://tinyurl.com/ }}$ 년 $6 q_{4} \mathrm{dc}>$

Paris, Bibliothèque nationale de France, français 2253 (La Belle Dame sans mercy) $<\underline{\text { https: / / }}$ tinyurl.com/yxfwukfw $>$

Paris, Bibliothèque nationale de France, français 2544I (Palamon et Arcita) https://tinyurl.com/ y6ge75jd

Paris, Bibliothèque nationale de France, n.a.f. 6513 (Palamon et Arcita)

Paris, Bibliothèque nationale de France n.a.fr. 7I9 (Palamon et Arcita)

\subsection{Manuscripts cited owned by Anne de Graville}

Bayerische Staatsbibliothek, cod. Gall. II (Christine de Pizan’s Mutacion de Fortune)

Paris, Bibliothèque de l'Arsenal 3 I72 (Christine de Pizan's Mutacion de Fortune) < $\underline{\text { https: / tinyurl. }}$ 
$\underline{\mathrm{com} / \mathrm{y} \text { 4gzekrd> }}$

\subsection{Manuscripts cited containing works by Alain Chartier}

Berlin, Staatliche Museen Preubischer Kulturbesitz, Kupferstichkabinett MS 78.B.I7 (the Rohan Chansonnier, made for Louis de Graville)

Fribourg, bibliothèque cantonale et universitaire Ms L I200 < $<$ https://tinyurl.com/y3qmbfzh $>$

Grenoble, bibliothèque municipale 874 (base manuscript for Ye 838)

Hatfield, Hatfield House, Cecil Papers 297

New York, Pierpoint Morgan Library 396 (early I $^{\text {th }}$ century manuscript related to BN fr II3I and St. Petersburg

Paris, Bibliothèque nationale de France, français 924 (manuscript belonged to Jacques Thiboust) $<\underline{\text { https://tinyurl.com/y2gyx } \mathrm{h}_{5}>}$

Paris, Bibliothèque nationale de France, français II3I (base manuscript for Hult and McRae) <https://tinyurl.com/yxls4ynz>

Paris, Bibliothèque nationale de France, français 2230 (made for Marguerite de Rohan) $<\underline{\text { https: } / /}$ tinyurl.com/yysrwpcj>

Paris, Bibliothèque nationale de France, français I9I39 (compilation of Chartier and Charles d'Orléans) < $\underline{\text { https://tinyurl.com/y6jh3vfl }>}$

Paris, Bibliothèque nationale de France, français 20026 (made for Marie de Clèves) <https:// tinyurl.com/y43d2s5p $>$

St. Petersburg, MS fr. ${ }^{\circ}$ v. XIV. ooo 7

Toulouse, bibliothèque municipale 826 (Base for Laidlaw) $<$ https://tinyurl.com/yzypnljk $>$

Vatican, Regina Lat. I683 (Chartier's works along with Pierre Nesson’s Lai de Guerre)

Yale, Beinecke Library, I2 6 (the Clumber Park Chartier) < $\underline{\text { https://tinyurl.com/y6c4vvza }>}$

\subsection{Early printed editions}

Paris, Bibliothèque nationale de France (Y. 6I56. B. 2; Inv. Réserve Ye 838) <https://tinyurl.com/ $\underline{\mathrm{y} 6 \mathrm{kxfoon}>}$

Paris, Bibliothèque nationale de France, Rothschild $443[\mathrm{IV}, 4,85]<\underline{\text { https: } / / \text { tinyurl.com/y5z7qftc }}>$

\subsection{Other}

Cambridge, Fitzwilliam MS I59 (primer that belonged to Claude de France) $<\underline{\text { https://tinyurl.com/ }}$ yxkxbynp> 